\title{
Účinnost' všeobecného a kombinovaného silového tréningu na zmeny rýchlostno-silových schopností mladých hokejistov
}

\section{Effects of combined strength training on changes in speed-strength performance in young hockey players}

\author{
Vanderka Marián, Kabát Milan
}

Fakulta telesnej výchovy a športu, Univerzita Komenského, Bratislava, Slovensko

\section{ABSTRAKT}

Ciel’om výskumu bolo overit' účinnost' dvoch odlišných typov silového tréningu. Všeobecného zameraného na rozvoj svalovej topografie a kombinovaného - maximálne silového a plyometrického tréningu na zmeny všeobecných a špeciálnych rýchlostno-silových schopností 12-tich mladých hráčov l'adového hokeja. Išlo o jednoskupinový postupný kvázi-experiment v trvaní 8 týždňov s frekvenciou podnetov 2 krát týždenne v troch sériách cvičení. Prvé 4 týždne absolvovali mladý hokejisti základný silový tréning zameraný na topografiu všeobecnými prostriedkami (6-8 cvičení, 3 série, 70\% - 80\% 1 RM s počtom opakovaní 8-10). Druhé 4 týždne bol silový tréning kombinovaný a pozostával s maximálne silových metód (2-4 opakovania s 85-95\% 1RM) a následnou aplikáciou plyometrických cvičení v 6-10 opakovaniach v jednej tréningovej jednotke. Sledovali sme zmeny parametrov pohybovej výkonnosti v špecifických a v nešpecifických podmienkach. Výsledky preukázali nasledovné zmeny: Vo vertikálnom výskoku bez protipohybu (SJ) sme zaznamenali po období kombinovaného tréningu (EX2) zlepšenie z 33,3 $\pm 2,89 \mathrm{~cm}$ na 34,35 $\pm 2,80 \mathrm{~cm}$ čo je nárast o $1,05 \mathrm{~cm}(3,2 \% ; p<0,01)$; vo výskoku s protipohybom (CMJ) nastalo zlepšenie z 36,51 $\pm 4,39 \mathrm{~cm}$ na 37,84 $\pm 4,36 \mathrm{~cm}$ o $1,33 \mathrm{~cm}$, čiže o 3,6\% (p<0,01). $V$ období rozvoja všeobecnej svalovej topografie (EX1) nastal v parametri vertikálny výskok bez protipohybu (SJ) tiež významný nárast z 32,48 $\pm 3,65 \mathrm{sm}$ na 33,3 $\pm 2,89 \mathrm{~cm}(p<0,05)$. Anaeróbny alaktátový výkon (AAV) bol pozitívne ovplyvnený obidvomi experimentálnymi podnetmi. V EX1 z 42,09 \pm 4,48 W.kg-1 na 42,72 \pm 4,61 W. kg-1 (p<0,01) a neskôr v EX2 na 43,78 44,44 W.kg-1 (p<0,01). V testoch odrazových schopností zložitejšieho charakteru sme takisto zaregistrovali pozitivne zmeny, čo sa prejavilo zlepšením výkonov vobidvoch obdobiach. $V$ skoku do dial'ky z miesta (SZM) v EX1 období z 246,25 $\pm 11,07 \mathrm{~cm}$ na 249,17 $\pm 10,32 \mathrm{~cm}$ ( $p<0,01)$ a následne na 253,58 $\pm 9,83 \mathrm{~cm} v$ EX2 (p<0,01). V trojskoku (3SK), teste na rýchlost' so zmenami smeru (10x5) a v testoch na l'ade boli významné prírastky iba v obdobi kombinovaného tréningu (EX2). V teste $3 S K$ z 722,42 $\pm 29,58 \mathrm{~cm}$ na 727,50 $\pm 30,64 \mathrm{~cm} ; v$ teste $10 x 5 \mathrm{~m}$ z 17,00 $\pm 0,57 \mathrm{~s} \mathrm{na} \mathrm{16,90 \pm 0,57} \mathrm{s} \mathrm{(} p<0,01) ; v$ teste korčuliarskej rýchlosti $(1 \times 36 m)$ z 4,95 $\pm 0,10$ s na 4,88 $\pm 0,09$ s o 1,4\% (p<0,01); v teste korčuliarskej rýchlosti so zemami smeru (6x9m)

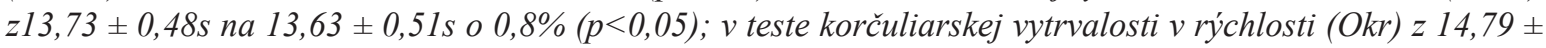
$0,18$ s na $14,67 \pm 0,20$ s o 0,8\% ( $<<0,05)$. V parametroch testu špeciálnych zručností - rýchlosti s vedením puku (Sla) nenastali významné zmeny ani v jednom období. Záverom môžeme konštatovat', že kombinovaný tréning (maximálna sila a plyometria) mal v porovnaní s tréningom všeobecnej sily viac pozitívny vplyv na rozvoj rýchlostno-silových schopností mladých hráčov l'adového hokeja, ktorý sa prejavil aj v špecifických podmienkach hodnotenia pohybovej výkonnosti na l'ade.

\section{ABSTRACT}

Purpose of this study was to compare effects of general strength training with combined maximal strength and plyometrics training. Twelve young ice hockey players were examined and intervened 4-week general strength training (EX1) at first and consequently 4-week, combined training (EX2). Combined training consisted of maximal strength workouts with 2-4 repetitions on 85-95\% 1RM and subsequent application of plyometrics workouts with 6-10 repetitions. The training group performed 2 sessions per a week in 3 sets of exercises. The measurements were assessed before, between and after periods and consisted of specific test performed on ice and non-specific tests off ice. The results showed that in EX2 period SJ improved from 33,3 $\pm 2,89 \mathrm{~cm}$ to $34,35 \pm 2,80 \mathrm{~cm}$ by $1,05 \mathrm{~cm}(3,2 \%$; $<<0,01)$; CMJ from $36,51 \pm 4,39 \mathrm{~cm}$ to $37,84 \pm 4,36 \mathrm{~cm}$ by $1,33 \mathrm{~cm}(3,6 \%$; $p<0,01)$. Also in EX1 period SJ was changed from $32,48 \pm 3,65 \mathrm{~cm}$ to $33,3 \pm 2,89 \mathrm{~cm}(p<0,05)$. Anaerobic alactic 
power (AAV) changed significantly in EX1 period from 42,09 \pm 4,48 W.kg-1 to 42,72 $\pm 4,61 \mathrm{~W} . \mathrm{kg}-1$ (p<0,01) afterwards in EX2 period to 43,78 $\pm 4,44 \mathrm{~W} . \mathrm{kg}-1$ ( $p<0,01)$. In jumping performances we measured in both periods significant improvements; standing long jump (SZM) in EX1 period from 246,25 $\pm 11,07 \mathrm{~cm}$ to 249,17 $\pm 10,32 \mathrm{~cm}(p<0,01)$ then in the end of EX2 period 253,58 $\pm 9,83 \mathrm{~cm}(p<0,01)$. Standing triple jump (3SK), agility run (10x5) and all specific test on ice were significant changes recorded only in EX2 period. $3 S K$ from $722,42 \pm 29,58 \mathrm{~cm}$ to $727,50 \pm 30,64 \mathrm{~cm} ; 10 x 5 \mathrm{~m}$ from $17,00 \pm 0,57 \mathrm{~s}$ to16,90 $\pm 0,57 \mathrm{~s}(\mathrm{p}<0,01)$; on ice speed tests (1x36m) from 4,95 $\pm 0,10 \mathrm{~s}$ to 4,88 $\pm 0,09 \mathrm{~s}$ by 1,4\% ( $<<0,01)$; ( $6 x 9 \mathrm{~m})$ from 13,73 $\pm 0,48 \mathrm{~s}$ to 13,63 $\pm 0,51$ $s$ by 0,8\% ( $<<0,05)$; in speed endurance ice hockey skating test (Okr) form 14,79 $\pm 0,18 \mathrm{~s}$ to 14,67 $\pm 0,20 \mathrm{~s}$ $o$ 0,8\% ( $<<0,05)$. Skills ice hockey test parameters (Sla) did not changed significantly in EX1 neither in EX2 period. It could be concluded that both periods had effect on motor performance enhancement, but EX2 training period was more sufficient for improvement in speed-strength abilities especially in specific condition on ice.

Kl'účové slová: l'adový hokej, rýchlostno-silové schopnosti, kombinovaný tréning, plyometria

Key words: ice hockey, speed-strength abilities, combined training, plyometrics

\section{ÚVOD}

V súčasnosti l'adový hokej zaznamenáva zvýšené nároky na pohybové schopnosti a zručnosti jednotlivých hráčov, čo si vyžaduje intenzívny dôraz na ich rozvoj. Z hl'adiska dĺžky trvania, vel'kosti objemu a intenzity sa tréningový proces posunul do vyšších dimenzií kondičného a športového tréningu, pričom rapídne stúpla požiadavka na aplikovanie vedeckých poznatkov do jeho systému. Podiel nielen silových schopností na výkone stúpol do takej miery, že jednotlivé formy silového prejavu sa musia rozvíjat' takým spôsobom, ktorý umožňuje ich optimálny rozvoj s maximálnym využitím v zápase.

Vysoký stupeň rozvoja kondičných a koordinačných schopností umožňuje využívat' racionálnu technickú zručnost', efektívne taktické myslenie so zapojením osobnostných predpokladov hráča (LACZO, 2009; TÓTH, 2010). Herný výkon hráča v zápase pozostáva s krátkych, opakovaných, vo väčšom podiele intenzívnych pohybov. VEILLETTE (2008) uvádza, že počet striedaní za zápas je 17 krát, pričom čas strávený na l'ade je 85 s. Počas neho je hráč približne $40 \mathrm{~s}$ v zat’ažení (v maximálnom, strednom, aj nízkom) a $45 \mathrm{~s}$ bez zat’aženia po prerušení hry. Preto treba zabezpečit' maximálny rozvoj limitujúcich faktorov, ktoré z hl'adiska pohybových schopností pozostávajú s rýchlostno-silových schopností s dôrazom na koordináciu pohybov.

Rozvoju pohybových schopností sa zameriavame aj priamo v sút’ažných cykloch. Sút'ažné obdobie v l'adovom hokeji predstavuje z časového hl'adiska najdlhšiu čast' a býva problém s udržaním získanej formy. Príčinu hl'adáme vo frekvencii zápasov počas sút’aže, v ktorej sa priemerne odohrajú 3 zápasy za týždeň, z čoho pramení k pokles formy. Preto je nutné podrobovat' sa tréningovému procesu aj mimo l’adu na stimuláciu bioenergetických zásob, aktivizáciu jednotlivých svalových štruktúr, ale aj na regeneračné procesy prostredníctvom kompenzácie jednostranného zat’ǎenia (KOSTKA-BUKAČ-ŠAFǍ̌́IK, 1986; LACZO, 2009; LACZO in TÓTH a kol., 2010). V tréningovom procese je žiaduce pôsobit' na tie faktory, ktoré zohrávajú rozhodujúcu úlohu v športovom výkone hráča. Tréningová činnost' sa prispôsobuje harmonogramu zápasov hlavnom období, aktuálnemu fyzickému a psychickému stavu jednotlivca alebo celého tímu.

Základnou črtou kondičného programu v sút’ǎnom období je, že sa znižuje celkový objem vykonanej práce, pričom intenzita sa minimálne udržuje. Štarty v zápasoch, ktoré by mali stimulovat' limitujúce a optimalizujúce faktory, z hl'adiska intenzity zat'aženia nemusia byt' dostatočné, čo z dlhodobejšieho hl'adiska môže mat' negatívny vplyv na výkon (MORAVEC a kol., 2007; VANDERKA, 2008).

RONNENSTAD-NYMARK-RAASTAD (2011) skúmali vplyv frekvencie silových podnetov na udržanie prírastkov sily nadobudnutej počas prípravného obdobia. Jedna skupina vykonávala silový tréning na udržanie získanej sily v prípravnom období 1 krát do týždňa a druhá 1 krát za 2 týždne. Obe skupiny sa podrobili testovaniu pred a na konci 12 týždňovému programu (vo vertikálnom výskoku, v silových parametroch a $40 \mathrm{~m}$ šprint). Výsledkom skúmania bolo, že skupina, ktorá vykonávala 1 silový tréning za týždeň, si dokázala štatisticky významne udržat' sledované silové parametre a výkon v teste $40 \mathrm{~m}$ šprint na rovnakej úrovni. Naopak druhej skupine s tréningom 1 krát za 2 týždne sa signifikantne znížili sledované silové a rýchlostné parametre $(\mathrm{p}<0,05)$. Z uvedeného môžeme dedukovat', že zápasy pravdepodobne neposkytujú dostatočný stimul na rýchlostné a silové schopnosti, a preto vzniká potreba neustálej aktivizácie bioenergetických a funkčných komponentov organizmu prostredníctvom vložených TJ mimo hlavného tréningové procesu. 
Nešpecifickými tréningovými jednotkami mimo hlavného tréningového procesu sa zaoberali aj CHELLY et al. (2010), kde sa jedna skupina futbalistov podrobila plyometrickému tréningu 2 krát týždenne navyše, v porovnaní s kontrolnou skupinou, ktorá vykonávala typický futbalový tréning. Experimentálna skupina zaznamenala signifikantné zlepšenia v sledovaných rýchlostno-silových parametroch.

MEYLAN - MALATESTA (2009) sa venovali rozvoju explozívnych činností ako sú skoky, odrazy, zmeny smeru u mladých futbalistov v sút’ažnom období a zaznamenali signifikantné a pozitívne zmeny vo všetkých sledovaných rýchlostno-silových parametroch.

Ciel'om kondičného programu mimo l'adu je zamedzit' tomuto poklesu a stabilizovat' získanú úroveň silových a rýchlostno-silových schopností. Preto sa hl’adajú nové formy a metódy, ktoré by odstránili alebo čiastočne eliminovali tento deficit. Kombinovaný tréning sa ukazuje ako jedna z možných foriem rozvoja trénovanosti, pretože spája v sebe atribúty, ktoré dovol'ujú uplatňovat' metódy rozvoja jednotlivých schopností, ktorých výsledkom je žiadaný efekt. ZEMKOVÁ a HAMAR (2010) vo svojom výskume overovali vplyv kombinovaného tréningu (6 týždňov, 4 TJ.týždeň-1), kde spájali tréning na rozvoj agility a rovnováhovej schopnosti na neuromuskulárnu adaptáciu basketbalistov. Prostredníctvom kombinovaného tréningu sa sledovaná skupina zlepšila v štartovej rýchlosti, v diferenciácii sily počas svalovej kontrakcie a navyše sa skrátil čas dotyku s podložkou pri opakovaných odrazoch. V dynamickej rovnováhe sa zlepšila percepcia pohybu bez vizuálnej kontroly, skrátil sa čas reakcie na multivýberový podnet a signifikantne sa zlepšil výkon vo výskoku s protipohybom.

Takisto aj VILLARREAL - IZQUIERDO - GONZALEZ BADILLO (2011) uskutočnili výskum, kde overovali efekt 5 odlišných tréningových stimulov. Porovnávali efekt kombinovaného silového tréningu a tréningu s rozvojom maximálnej sily, maximálneho silového výkonu a s efektom plyometrického tréningu samostatne. Po 7 týždňoch implementácie jednotlivých podnetov zistili, že nie len „samostatné“ tréningové jednotky na rozvoj jednotlivých schopností, ale aj kombinovaný tréning poskytuje pozitívny tréningový stimul na zlepšenie odrazových, rýchlostno-silových schopností.

MANGINE et al. (2008) sa venovali podobnému programu ako my, čiže kombinovali maximálnu silu $\mathrm{s}$ balistickým princípom pohybu a zaznamenali zlepšenia u experimentálnej skupiny v testoch 1RM tlak na lavičke $(\mathrm{p}<0,04)$, výkon $\mathrm{v}$ teste podrep-výskok $(\mathrm{p}<0,02)$, pričom kontrolná skupina sa podrobila klasickému protokolu na rozvoj maximálnej sily.

Takisto aj SANTOS a JANEIRA (2008) skúmali vplyv kombinovaného tréningu počas sút’ažnej sezóny na zmeny explozívnej sily 25-tich adolescentov a signifikantne sa zlepšili vo výskoku bez a s protipohybom, vo výskoku zo sedu.

Na základe výsledkov uvedených štúdií sa domnievame, že kombinovaný tréning (maximálne silové podnety s následnou aplikáciou plyometrickej metódy) môže vplývat' aj v sút'ažnom období pozitívnejšie na zmeny rýchlostno-silových mladých hokejistov ako tréning všeobecnej sily zameranej na svalovú topografiu.

\section{CIEL}

Posúdit' efektívnost' všeobecného (topografia) a kombinovaného (maximálne silového a plyometrického) tréningu na zmeny rýchlostno-silových schopností mladých hokejistov. Prostredníctvom porovnania zmien motorickej výkonnosti vo všeobecných a špeciálnych motorických testoch prispiet’ k objektivizácii zat’ažovania kondičného charakteru v mládežníckom hokeji.

\section{METODIKA}

Výskumný súbor úbor tvorilo 12 chlapcov vo veku $16,76 \pm 0,19$ rokov, pričom priemerná telesná výška bola $175,58( \pm 7,91) \mathrm{cm}$ a priemerná hmotnost' súboru 75,08 \pm 7,99 kg..

Išlo o jednoskupinový postupný kvázi-experiment prebiehajúci 8 týždňov, v ktorom sa testovaný súbor podrobil 4-týždňovému rozvoju všeobecnej sily zameranej na rozvoj svalovej topografie experimentálne obdobie 1 (EX1). Po ňom nasledoval 4-týždňový mezocyklus s aplikáciou kombinovaného tréningu, išlo o maximálne silový a plyometrický tréning (EX2). V obidvoch obdobiach absolvovali probandi dve tréningové jednotky silového tréningu týždenne, okrem hokejových tréningov a zápasov, ktorých charakteristiky zat’aženia boli v obidvoch obdobiach porovnatel'né. Sút’ažný mikrocyklus súboru pozostával zo 4 TJ na l'ade, z 2 TJ na suchu a 2 sút'ažných zápasov počas víkendov.

V období EX1 sme sa zamerali na rozvoj všeobecnej sily prostredníctvom cvičení a metód vykonávaných v posilňovni v objeme 6 - 8 cvičení, po 3 série, intenzita zat’aženia z hl'adiska vel'kosti odporu bola $70 \%$ - 80\% 
1 RM s počtom opakovaní 8 - 10 a intervalom odpočinku 2 min. V období EX2 sme využili kombinovanú metódu, kde objem TJ pozostával zo 7-9 cvičení, po 3 série, IZ 85\% - 90\% 1RM po 2 - 4 opakovania. Ihned' po ukončení, probandi vykonávali 6-10 plyometrických odrazov. Interval odpočinku medzi sériami trval 2 minúty. Zat’aženie malo postupnú gradáciu nielen objemu, ale aj intenzity (tab. 1 a 2).

Tab.1 Systém zvyšovania zat’aženia v experimentálnom období EX2

\begin{tabular}{|l|lll|}
\hline Týždeň & Maximálna sila & 1RM & Plyometria \\
\hline 1. & 3-4 p.o. & $85 \%$ & $6-8$ \\
\hline $\mathbf{2 .}$ & 2-3 p.o. & $90 \%$ & $6-8$ \\
\hline 3. & 2-4 p.o. & $90 \%$ & 8 \\
\hline 4. & 3-4 p.o. & $90 \%$ & $8-10$ \\
\hline
\end{tabular}

Tab.2 Príklady tréningových jednotiek v experimentálnom období EX2

\begin{tabular}{|l|l|l|l|l|l|}
\hline \multicolumn{5}{|l|}{ Experimentálne obdobie 2 } \\
\hline Utorok & $\begin{array}{l}\text { Série } \\
\text { počet } \\
\text { opakovaní }\end{array}$ & $\begin{array}{l}\text { Interval } \\
\text { odpočinku }\end{array}$ & Prostriedky & $\begin{array}{l}\text { Série } \\
\text { počet } \\
\text { opakovaní }\end{array}$ & $\begin{array}{l}\text { Interval } \\
\text { odpočinku }\end{array}$ \\
\hline $\begin{array}{l}\text { Leg-press + } \\
\text { preskoky }\end{array}$ & $3 \times 3 / 3 \times 6$ & $2-3$ min & $\begin{array}{l}\text { Leg-press + } \\
\text { preskoky }\end{array}$ & $3 \times 3 / 3 \times 6$ & $2-3$ min \\
\hline $\begin{array}{l}\text { znožmo } \\
\text { bokom }\end{array}$ & & znožmo vpred & & \\
\hline $\begin{array}{l}\text { Bench-press + } \\
\text { odrazy v } \\
\text { podpore ležmo }\end{array}$ & $3 \times 3 / 3 \times 6$ & $2-3$ min & $\begin{array}{l}\text { Bench-press + } \\
\text { odrazy v } \\
\text { podpore ležmo }\end{array}$ & $3 \times 3 / 3 \times 6$ & $2-3$ min \\
\hline $\begin{array}{l}\text { Výpady vzad + } \\
\text { korčuliarsky } \\
\text { skoky }\end{array}$ & $3 \times 3 / 3 \times 8$ & $2-3$ min & $\begin{array}{l}\text { Výpady vpred } \\
+ \text { korčuliarsky } \\
\text { skoky }\end{array}$ & $3 \times 3 / 3 \times 8$ & $2-3$ min \\
\hline $\begin{array}{l}\text { Prítah činky + } \\
\text { prehmaty } \\
\text { činky }\end{array}$ & $3 \times 3 / 3 \times 8$ & $2-3$ min & $\begin{array}{l}\text { Veslovanie }+ \\
\text { prehmaty } \\
\text { činky }\end{array}$ & $3 \times 3 / 3 \times 8$ & $2-3$ min \\
\hline $\begin{array}{l}\text { Drepy + } \\
\text { zoskok-výskok }\end{array}$ & $3 \times 3 / 3 \times 6$ & $2-3$ min & $\begin{array}{l}\text { Drepy + } \\
\text { zoskok-výskok }\end{array}$ & $3 \times 3 / 3 \times 6$ & $2-3$ min \\
\hline $\begin{array}{l}\text { Tlaky } \\
\text { jednoručiek }+ \\
\text { výskok na } \\
\text { stupienok }\end{array}$ & $3 \times 3 / 3 \times 6$ & $2-3$ min & $\begin{array}{l}\text { Tlaky } \\
\text { jednoručiek }+ \\
\text { výskok na } \\
\text { stupienok }\end{array}$ & $3 \times 3 / 3 \times 6$ & $2-3$ min \\
\hline Sed -l'ah & $3 / 3 \times 10-15$ & $1-2$ min & Sed - l'ah & $3 / 3 \times 10-15$ & $1-2$ min \\
\hline
\end{tabular}

Testovania sme vykonali pred a po EX1 a po EX2 období. Účinnost' tréningových podnetov sme hodnotili prostredníctvom zmien v pohybovej výkonnosti v motorických testoch (tab. 3). 
Tab.3 Použité motorické testy

\begin{tabular}{|c|c|}
\hline Nešpecifické testy ,na suchu“6 & Špecifické testy ,na l’ade“6 \\
\hline Vertikálny výskok bez protipohybu (SJ) & 36 m korčul'ovanie vpred $(1 \times 36)$ \\
\hline Vertikálny výskok s protipohybom (CMJ) & $6 \times 9$ metrov $(6 \times 9)$ \\
\hline Anaeróbny alaktátový výkon (AAV) & 1 okruh okolo brán (OKR) \\
\hline Skok do dial'ky z miesta (SZM) & Slalom s vedením puku (SLA) \\
\hline Trojskok znožmo (3SK) & \\
\hline Člnkový beh 10 x 5 metrov $(10 \times 5)$ & \\
\hline
\end{tabular}

Na získanie údajov o vertikálnych výskokoch ako aj na hodnotenie anaeróbneho alaktátového výkonu (10 sekundový test opakovaných výskokov, kritériom bol priemer troch najlepších vo Wattoch na kg telesnej hmotnosti) sme použili zariadenie FitroJumper. Údaje pri bežeckých a korčuliarskych výkonoch sme zaznamenávali fotobunkami.

$\mathrm{Na}$ zistenie štatistickej významnosti rozdielov vstupných a výstupných hodnôt sme použili Wilcoxono v t-test.

\section{VÝSLEDKY}

Výsledky v testoch „na suchu“ získané vo výstupných meraniach (tab. 4) indukujú, že po kombinovanom tréningu nastali nasledovné zmeny. Vo vertikálnom výskoku bez protipohybu (SJ) sme zaznamenali zlepšenie z $33,3 \pm 2,89 \mathrm{~cm}$ na $34,35 \pm 2,80 \mathrm{~cm}$ čo je nárast o $1,05 \mathrm{~cm}(3,2 \% ; \mathrm{p}<0,01)$ a s protipohybom (CMJ) nastalo zlepšenie z 36,51 $\pm 4,39 \mathrm{~cm}$ na 37,84 $\pm 4,36 \mathrm{~cm}$ o $1,33 \mathrm{~cm}$, čiže o $3,6 \%$ (p<0,01). V EX1 období rozvoja všeobecnej svalovej topografie nastal v parametri vertikálny výskok bez protipohybu (SJ) tiež nárast z 32,48 \pm $3,65 \mathrm{sm}$ na $33,3 \pm 2,89 \mathrm{~cm}(\mathrm{p}<0,05)$.

Anaeróbny alaktátový výkon (AAV) bol pozitívne ovplyvnený obidvomi experimentálnymi podnetmi (tab. 4). V Ex1 z 42,09 \pm 4,48 W.kg-1 na 42,72 \pm 4,61 W.kg-1 (p<0,01) a neskôr v EX2 na 43,78 \pm 4,44 W.kg$1(\mathrm{p}<0,01)$.

V testoch odrazových schopností zložitejšieho charakteru sme takisto zaregistrovali pozitívne zmeny, čo sa prejavilo zlepšením výkonov v obidvoch obdobiach v teste skok do dial'ky z miesta (SZM) EX1 z 246,25 $\pm 11,07 \mathrm{~cm}$ na $249,17 \pm 10,32 \mathrm{~cm}(\mathrm{p}<0,01)$ a následne na $253,58 \pm 9,83 \mathrm{~cm}$ v EX2 $(\mathrm{p}<0,01)$. V trojskoku (3SK) a teste na rýchlost' so zmenami smeru (10x5) bol významný iba prírastok období kombinovaného tréningu (EX2) z $722,42 \pm 29,58 \mathrm{~cm}$ na $727,50 \pm 30,64 \mathrm{~cm}$ a z $17,00 \pm 0,57 \mathrm{~s}$ na $16,90 \pm 0,57 \mathrm{~s}(\mathrm{p}<0,01)$.

Tab. 4 Výsledky testov „,na suchu“

\begin{tabular}{|c|c|c|c|}
\hline TEST & $\mathbf{t}_{\mathbf{0}}$ & $\mathbf{t}_{1}$ & $\mathbf{t}_{2}$ \\
\hline SJ [cm] & $32,48 \pm 3,65$ & $33,3 \pm 2,89 *$ & $34,35 \pm 2,80 * *$ \\
\hline CMJ [cm] & $36,0 \pm 4,37$ & $36,51 \pm 4,39$ & $37,84 \pm 4,36 * *$ \\
\hline AAV [W. $\left.\mathrm{kg}^{-1}\right]$ & $42,09 \pm 4,48$ & $42,72 \pm 4,61 * *$ & $43,78 \pm 4,44 * *$ \\
\hline SZM [cm] & $246,25 \pm 11,07$ & $249,17 \pm 10,32 *$ & $253,58 \pm 9,83 * *$ \\
\hline $3 S K[\mathrm{~cm}]$ & $721,25 \pm 29,18$ & $722,42 \pm 29,58$ & $727,50 \pm 30,64 * *$ \\
\hline $10 \times 5[s]$ & $16,95 \pm 0,58$ & $17,00 \pm 0,57$ & $16,90 \pm 0,57 * *$ \\
\hline
\end{tabular}

Po absolvovaní podnetu EX1 v čase t1 sme v sledovanom súbore nezaznamenali žiadne štatisticky významne pozitívne zmeny v parametroch testov realizovaných na l'ade (tab. 5). Po intervencii experimentálneho podnetu EX2 sme pri výstupných meraniach $\mathrm{t} 2$ zaznamenali nasledovné zlepšenie výkonov: v teste korčuliarskej rýchlosti $(1 \times 36 \mathrm{~m})$ z $4,95 \pm 0,10$ s na $4,88 \pm 0,09$ s o $1,4 \%$ (p<0,01); v teste korčuliarskej rýchlosti so zemami smeru $(6 \times 9 \mathrm{~m})$ $\mathrm{z} 13,73 \pm 0,48 \mathrm{~s}$ na $13,63 \pm 0,51 \mathrm{~s}$ o $0,8 \%(\mathrm{p}<0,05)$; v teste korčuliarskej vytrvalosti v rýchlosti $(\mathrm{Okr}) \mathrm{z} 14,79 \pm$ 0,18 s na $14,67 \pm 0,20$ s o $0,8 \%(p<0,05)$. Iba v teste špeciálnych zručností - rýchlosti s vedením puku (Sla) nenastali významné zmeny ani v jednom z období (tab. 5). 
Tab. 5 Výsledky testov, „na l’ade“

\begin{tabular}{|l|lll|}
\hline TEST & \multicolumn{1}{l}{$\mathbf{t}_{\mathbf{0}}$} & $\mathbf{t}_{\mathbf{1}}$ & $\mathbf{t}_{\mathbf{2}}$ \\
\hline $\mathbf{1 x 3 6}[\mathbf{s}]$ & $5,02 \pm 0,13$ & $4,95 \pm 0,10$ & $\mathbf{4 , 8 8} \pm \mathbf{0 , 0 9} * *$ \\
\hline $\mathbf{6 x 9}[\mathbf{s}]$ & $13,73 \pm 0,56$ & $13,73 \pm 0,48$ & $\mathbf{1 3 , 6 3} \pm \mathbf{0 , 5 1} *$ \\
\hline Okr $[\mathbf{s}]$ & $14,83 \pm 0,21$ & $14,79 \pm 0,18$ & $\mathbf{1 4 , 6 7 \pm \mathbf { 0 , 2 0 }} *$ \\
\hline Sla $[\mathbf{s}]$ & $12,42 \pm 0,35$ & $12,48 \pm 0,33$ & $12,48 \pm 0,35$ \\
\hline $\mathrm{p}<0,01=* * ; \mathrm{p}<0,05=*$ & & \\
\hline
\end{tabular}

\section{DISKUSIA}

Navrhnutý tréningový protokol bol relatívne optimálny na rozvoj rýchlostno-silových schopností, ale je nutné pripomenút' niekol'ko dôležitých momentov, ktoré mohli ovplyvnit' získané výsledky. Zistili sme, že vo všetkých testoch „na suchu“ sme sa zlepšili štatisticky významne $(\mathrm{p}<0,01)$ v porovnaní s priebežným testovaním po kontrolnom období. V testoch SJ a CMJ sme sa priemerne zlepšili o 3,2\%, resp. 3,6\%. Naše výsledky korešpondujú s výsledkami MARKOVIČA (2007), ktorý sa zosumarizoval 26 štúdií zaoberajúcich sa vplyvom plyometrického tréningu na rozvoj odrazových schopností. V jeho metaanylýze popisuje zlepšenia výkonov v SJ od 1,8 do $7,6 \%(\mathrm{p}<0,05)$. Naopak v teste CMJ sa úroveň zlepšenia výkonov pohybovala medzi 7,0 až 10,4\% $(\mathrm{p}<0,05)$, čo nezapadá do kontextu nami získaných výsledkov.

Aj v AAV, SZM a 3SK sa naši probandi štatisticky významne zlepšili $(p<0,01)$. Zlepšenie sledovaných výkonov môže byt' pravdepodobne zapríčinené zvýšenou dynamickou silou dolných končatín. Takisto aj zlepšená synchronizácia zapájaných svalových slučiek dolných končatín pri odrazoch v podobe zvýšenia počtu a časovej harmonizácie zapojenia motorických jednotiek, ktoré pravdepodobne nastali pôsobením maximálne silového podnetu. Odrazové cvičenia boli vykonávané po odcvičení silových podnetov v relatívnej únave, bolo nutné zvýšené svalové napätie a úsilie ako pri plyometrickom cvičení v odpočinutom stave. Je možné, že bolo využívané zvýšené množstvo elastickej energie ako prejavu adaptácie organizmu, ktoré nastáva po absolvovaní plyometrických cvičení.

Ďalej sme predpokladali, že experimentálny činitel' EX2 bude mat' pozitívny vplyv aj na výsledky testov vykonávaných na l'ade. V teste 1x36 zlepšenie nastalo napriek tomu, že sme nevykonávali žiadne špeciálne cvičenia na rozvoj rýchlostných schopností na l'ade, okrem klasického tréningu na l'ade. Vplyvom EX2 sa zvýšila dynamická sila dolných končatín, čo sa pravdepodobne prejavilo účinnejším, silnejším odrazom pri korčul'ovaní. Test 6x9 je prejav rýchlostno-silových schopností s výraznejšou mierou silového komponentu. Je to spôsobené zmenami smeru a brzdením, čo si vyžaduje vyšší nárok na silovú prípravu a pri brzdení na korčuliach sa tento podiel dynamickej sily zvyšuje. Plyometrickými cvičeniami sme pravdepodobne ovplyvnili aj využitel'nost' potenciálnej elastickej energie pri zmenách smeru na korčuliach.

V SLA sme nezaznamenali žiadne zlepšenia, dokonca priemerný výkon priebežných a výstupných meraní bol identický. SLA je technická disciplína, ktorá si vyžaduje roky tréningu. Naše podnety nevytváral také podmienky, ktoré by priniesli pozitívne zmeny v tomto teste. Je pre to nutné vykonávat' také cvičenia, ktoré by umožnili transfer získaných kondičných schopností do techniky vykonávania pohybu.

Experimentálny podnet nasledoval po ukončení kontrolného obdobia, v ktorom probandi vykonávali tréning zameraný na všeobecný silový rozvoj. Získané výsledky vo výstupných meraniach mohli ovplyvnit’ oneskorené a kumulatívne efekty. Adaptácia organizmu na všeobecný silový podnet sa mohol prejavit' v dlhšom časovom horizonte. Existuje pravdepodobnost', že oneskorený a kumulatívny efekt spolu s experimentálnym činitel'om EX2 maximalizovali sledované parametre vo výstupných meraniach.

Dížka trvania experimentálneho podnetu nebola priamo v kontexte so všeobecnými adaptačnými princípmi pri rozvoji kondičných schopností. Na druhej strane výskum ESCAMILLA et al. (2010) potvrdzuje, že aj za 4 týždne je možné ovplyvnit' sledované kondičné schopnosti. Sledovali vplyv kondičného programu na rýchlost' hodu loptičky mladých bejzbalistov. Prostredníctvom silového tréningu a programu zameraného na hody zaznamenal signifikantné zlepšenie výkonov v rýchlosti hodu loptičky $(p \leq 0,05)$ už po absolvovaní 4-týždňového mezocyklu rozvoja kondičných schopností, pričom probandi sa venovali aj klasickému bejzbalovému tréningu.

$\mathrm{Aj}$ faktor všeobecného adaptačného syndrómu a prirodzeného vývinu pravdepodobne ovplyvnili intraindividuálne odlišné reakcie našich probandov na relatívne rovnaké tréningové podnety. Z toho vyplýva, 
že aj všeobecne silovo orientovaný tréning dokáže ovplyvnit’ rýchlostno-silové parametre.

Realizovaný výskum odokryl aj nedostatky pri hodnotení a analyzovaní výsledkov. Treba eliminovat' vplyv všeobecne silového tréningu (EX1) tak, aby sme jasne vedeli definovat' prínos experimentálneho činitel'a (EX2), čo je vo vrcholovom športe pomerne zložitý problém. Vhodné by bolo realizovat' dvojskupinový experiment s dlhším časovým pôsobením jednotlivých podnetov.

\section{ZÁVER}

- Kombinovaný tréning (maximálna sila a plyometria) mal v porovnaní s obdobím tréningu svalovej topografie viac pozitívny vplyv na rozvoj rýchlostno-silových schopností mladých hráčov l'adového hokeja.

- Obdobie rozvoja všeobecnej sily malo tiež pozitívny efekt na zmeny niektorých ukazovatel’ov rýchlostno-silových schopností (SJ, AAV a SZM).

Pravdepodobne aj následnost' použitých metód vytvárala isté oneskorené a kumulatívne efekty, ktorých vplyv by bolo vhodné vylúčit' metodologicky čistejším dvojskupinovým experimentom.

V sút’ažnom období odporúčame viac využívat' kombinovaný silový tréning (maximálne silové podnety s následnou aplikáciou plyometrickej metódy) minimálne 1-2x týždenne a tréning všeobecnej sily zameranej na svalovú topografiu zarad'ovat' blokovo v prípade výrazného poklesu úrovne kondičných schopností.

Pri aplikácii kombinovaného tréningu odporúčame vykonat' 6-7 cvičení s hmotnost’ou 85-95\% 1RM v 2-4 opakovaniach a čo najskôr (ihned' po) vykonat' sériu 6-10 plyometrických odrazov to celé v minimálne v 3 sériách. Vždy so snahou o čo najväčšiu rýchlost' najmä v aktívnej fáze pohybu. Je vhodné využívat' najmä komplexné viackíbové cvičenia s orientáciou na dolné končatiny, ktoré v hokeji nesú hlavné zataženie.

\section{Literatúra}

CHELLY, M.S., GHENEM, M.A., ABID, K, et al. 2010. Effects of in-season short-term plyometric training program on leg power, jump- and sprint performance of soccer players. In: The journal of strength and conditioning research., 2010, Vol. 24, No. 10, pp. 2670-2676 ISSN 1064-8011.

ESCAMILLA, F.R., FLEISIG, G.S., YAMASHIRO, K., MIKLA, T., DUNNING, R., PAULOS, L., ANDREWS, J.R. 2010. Effects of a 4-week youth baseball conditioning profram on throwing velocity. In: The journal of strength and conditioning research., 2010, Vol. 24, No. 12, pp. 3247-3254. ISSN 1064-8011.

KOSTKA, V. - BUKAČ, L. - ŠAFǍ̌ÍK, V. 1986. Ledni hokej - teorie a didaktika. 1. vydanie. Praha: SPN Praha, 1986. 188 s. ISBN 14-326-86.

LACZO, E., 2009. Obsahové zameranie letnej kondičnej prípravy v l’adovom hokeji In Telesná výchova a šport, 2009, Vol. 19, No.2, pp. 22-25. ISSN 1335-2245.

MANGINE, G.T., RATAMESS, N.A., HOFFMAN, J.R., FAIGENBAUM, A.D., KANG, J., CHILAKOS, A. 2008. The effect of combined ballistic and heavy resistance training on maximal lower and upper body strength in recreattionally trained men. In: The journal of strength and conditioning research. 2008, Vol. 22, No. 1, pp. 132-135. ISSN 1064-8011.

MARKOVIC, G. 2007. Does plyometric training improve vertical jump height? A meta-analytical review. British journal of sports medicine, Vol. 41, No.6, pp. 349-355.

MEYLAN, C., MALATESTA, D. 2009. Effects of in-season plyometrics training within soccer practice on explosive actions of young players. In: The journal of strength and conditioning research. 2009, Vol. 23, No. 9, pp. 2605-2613. ISSN 1064-8011.

MORAVEC, R., KAMPMILLER, T., LACZO, E., VANDERKA, M. 2007. Teória a didaktika výkonnostného a vrcholového športu. 1 vyd., FTVŠ UK SVSTVŠ SOV, 240 s. ISBN 978-80-89075-31-7.

RONNESTAD, B., NYMARK, B., RAASTAD, T. 2011. Effects of in-season strength maintenance training frequency in professional soccer players. In: The journal of strength and conditioning research., 2011, Vol. 25, No. 10, pp. 2653-2660. ISSN 1064-8011.

SANTOS, E., JANEIRA, M. 2008. Effects of complex training on explosive strength in adolescent male basketball players. In: The journal of strength and conditioning research., 2008, Vol. 22, No. 3, pp. 903-909. ISSN 1064-8011.

TÓTH, I., HAMAR, D., GREGOR, T. a kol. 2010. L’adový hokej. 1. vydanie, TO-MI Ice hockey Agency, 2010, 
392 s., ISBN 978-80-970545-0-2.

VANDERKA, M. 2008. Silové a rýchlostno-silové schopnosti v kondičnej príprave športovcov. 1. vydanie. Bratislava: ICM AGENCY, 2008. 92 s. ISBN 978-80-89257-10-2.

VEILlETE, R. 2008. Physical development for hockey. [Online] Publikované 2.-5. mája 2008, Medzinárodná trénerská konferencia, Université Laval - Quebec City, Canada [citované 17. januára 2012]. Dostupné z www.szlh.sk/metodicke-oddelenie/seminare-zo-sveta

VILLARREAL, E., IZQUIERDO, M., GONZALEZ-BADILLO, J. 2011. Enhancing jump performance after combined vs. maximal power, heavy-resistance, and plyometric training alone. In: The journal of strength and conditioning research., 2011, Vol. 25, No. 12, pp. 3274-3281. ISSN 1064-8011.

ZEMKOVÁ, E. and HAMAR, D. 2010. The effect of 6-week combined agility training on neuromuscular performance in basketball players. In: The journal of sport medicine and physical fitness, 2010, Vol. 50, No. 3, pp.260-267. ISSN 88-7711-558-0. 